\title{
LAST WORDS
}

It is difficult to find a good title for an editorial page or a personal column: all the good ones have been used up. In the nineteenth century it was customary to adopt such a caption as "The Editor's Easy Chair," but that suggests a leisureliness in whose luxury we cannot indulge in the modern age. And I have always had the feeling too that there was something not quite candid about it even in that remote time-for no editor's chair is, or ever has been, an easy one.

Be that as it may, having chosen the motto above, faute de mieux, the Editor is considerably embarrassed for the nonce by the reflexion that on this occasion his last words are really his first-as editor of the Journal (if the reader can overlook the fact that he has already monopolized half of the present number). And in these first "Last Words" he wants to pay tribute to his predecessor, the retiring editor of the Journal, Professor Rudolf Kirk, who conceived and founded this organ of the Associated Friends of the Library of Rutgers University just eleven years ago. Sparing the blarney usual on such occasions, it may be said in simple truth that each number of the Journal under his editorship carried the name of Rutgers throughout the country in a way likely to establish and extend its intellectual prestige far better than an equal number of sensational news stories.

The present editor plans no radical changes in the character of the Journal, though there may be some differences of emphasis, for, as the reader has already seen, he has his idiosyncrasies. But with a keenly interested and level-headed Librarian and several able assistants at his elbow he is not likely to go far off an even course.

Readers who have come this far may already have heard enough for once of the Symington Collection, but we promise them more particulars of some parts of it in future numbers. We can employ our last words on this occasion in no better way than in affirming our belief that although the acquisition of individual volumes is necessary to every library, none becomes really important or distinguished except by coming into possession of collections such as the Symington Library, the result of years of collecting in a single field. This is a thought-a last word-to leave with all Friends of the Rutgers Library. 